\title{
Increased Exhalated Carbon Monoxide, Smoking and Obstructive Sleep Apnea
}

\author{
MIHAELA TRENCHEA ${ }^{1}$, AGRIPINA RASCU2 ${ }^{2}$, MARINA RUXANDRA OTELEA ${ }^{3 *}$, EDWIN SEVER BECHIR ${ }^{4}$, ELENA DANTES ${ }^{1}$, \\ DOINA ECATERINA TOFOLEAN ${ }^{1}$, ILEANA ION ${ }^{1}$, OANA CRISTINA ARGHIR ${ }^{1}$ \\ ${ }^{1} O$ vidius University of Constanta, Medicine Faculty, 124 Mamaia Blvd, 900527, Constanta, Romania \\ 2 University of Medicine and Pharmacy Carol Davila, Clinical Department 5, Bucharest, 37 Dionisie Lupu Str., 020021, Bucharest, \\ Romania \\ ${ }^{3}$ University of Medicine and Pharmacy Carol Davila, Clinical Department 2, Bucharest, 37 Dionisie Lupu Str., 020021, Bucharest, \\ Romania \\ ${ }^{4}$ University of Medicine and Pharmacy Targu Mures, 38 Gheorghe Marinescu Str, 540139, Targu Mures, Romania
}

\begin{abstract}
Although exhaled carbon monoxide (CO) is studied from decades, a few studies are about its levels in smokers with obstructive sleep apnea (OSA). The average level of exhaled CO (eCO) was determined in OSA smokers and found increased significantly higher than in patients with other breathing related sleep disorders. A gender significant difference in average eCO was also noticed, with higher numbers in men, in OSA patients. A threshold of the eCO $\geq 6$ ppm has $100 \%$ specificity and $96.3 \%$ sensitivity in detection of the active smoking habit in patients with OSA. Among OSA comorbidities, only chronic obstructive pulmonary disease (COPD) seams to influence the increased eCO levels in OSA active smokers.
\end{abstract}

Keywords: CO, smoking, obstructive sleep apnea, breathing related sleep disorders, COPD

Carbon monoxide (CO) in human body has both exogenous and endogenous sources. The exogenous source is represented mainly by smoking, but significant higher levels, although smaller than the ones in active smokers, were found in domestic exposure to gas-fired water heaters [1]. The vast majority of the endogenous $\mathrm{CO}$ is the end product of the hem metabolism and requires an active microsomal heme oxygenase. Proper expression of the induced heme oxygenase and a certain level of CO formation is hypothesized to protect the lung from external aggression [2]. Some studies have shown that CO plays a role in the protection against lung inflammation and injury. Healthy smokers, for example, had higher values of eCO than nonhealthy smokers [3]. Although CO is considered a biomarker of oxidative stress, many unknown features about the action of this gaz in lung diseases are to be solved especially in patients with obstructive sleep apneea [4-6]. Experimental studies have show $\mathrm{n}$ a supressive role of $\mathrm{CO}$ on the pro-inflammatory citokines (TNF $\alpha$ - tumor necrosis factor alpha; IL1 $\beta$ - interleukin 1 beta; MIP1 $\beta$ - macrophage inflammatory protein-1 beta) and an increasement of the anti-inflammatory ones (IL10-interleukin-10) [7]. A positive anti-inflammatory effect was found in low dose inhalation of $\mathrm{CO}$ in COPD patients [2]. By now, contradictory results of breathing CO have been reported in chronic lung diseases attempting to include the CO level on the inflammatory biomarkers list [8-10]. Measuring eCO is a widely used method in monitoring smoking cessation programs. The eCO level is influenced by the speed [11] and the phase of exhalation [12]. The sleep-wake status has also an influence on the half time of $\mathrm{CO}$, which is longer during sleep (4-8 h) than during daytime (2-3h) in normal individuals [13]. Breathing related sleep disorders (BRSD) might influence the accumulation of $\mathrm{CO}$. As there are a few studies concerning the level of CO in smokers with breathing related sleep disorders, the aim of the study was to focuse on the evaluation of the relationship between OSA and exhaled CO in active smokers.

\section{Experimental part}

The study included adults diagnosed with breathing related sleep disorders (BRSD) in a sleep laboratory who informed consented to be investigated. Cases were considered patients diagnosed with obstructive sleep apneea (OSA), having an apneea - hypopnea index (AHI) $\geq 5$ obstructive or mixt (apneea and hypopnea) events / hour of sleep. The data base contained informations about smoking status, medical history, symptoms, clinical and paraclinical examination, including anthropometric indexes as body mass index (BMI), neck circumference (NC), waist circumference (WC) and eCO measurement. The procedure of BRSD diagnostic was the cardiopulmonary poligraphy (STARDUST II RESPIRONICS), which recorded the nasal respiratory flow, the blood $\mathrm{O}_{2}$ saturation, the cardiac frequency, the snoring, the body position and the respiratory effort during sleep. The validation of the diagnostics was based according to AASM definitions [14], updated in 2014 [15]. Other BRSD (nonOSA) consisted in upper airways resistance syndrome (UARR), considered if $\mathrm{AHI}<5 / \mathrm{h}$, with no significant desaturation and minimal blood $\mathrm{O}_{2}$ saturation $\left(\mathrm{SpO}_{2}\right) \geq 92 \%$; central sleep apnea, diagnosed if $A H I \geq 5 / h$, consisted of central apnea of hypopneas; and obesity-hypoventilation syndrome (OHS) defined by $\mathrm{BMI} \geq 30 \mathrm{~kg} / \mathrm{m}^{2}$ with an average $\mathrm{SpO}_{2}<90 \%$ in $>30 \%$ of the total duration of the sleep. BMI was calculated by dividing the weight to the square of the body height.

NC was measured in an horizontal plane below the thyroid cartilage, perpendicular to the long axis of the neck, while the WC was taken at the half distance between the last rib and the iliac crest, with a plastic tape measure. The measurement of eCO levels was assessed among cases with OSA versus patients with other BRSD (nonOSA), by Smokerlyzer (Bedfont Scientific Ltd.), an instrument that used an electrochemical sensor to analyse the exhaled air concentration of $\mathrm{CO}$ in the initial phase of expiration, when flow is maximal. Any patient must perform a sustained exhalation keeping a breathhold of 15 seconds and the limit of eCO detection is 1 ppm [12]. A threshold of eCO in the differentiation the active smokers from non smokers

\footnotetext{
* email: marina.otelea@umfcd.ro
} 
(or exsmokers) was calculated in cases. Statistical analysis was performed using an SPSS software (StatPlus:mac Pro, v6, 2018). OneWay ANOVA test wa used for parametrical variables, Mann-Whitney $\mathrm{U}$ and median test for the nonparametrical ones, Pearson correlation for normaly distributed variables and Spearman corelation for the ones that did not show normal distribution. A significance thereshold of $95 \%$ was considered for significant.

\section{Results and discussions}

From a total population of 306 patients mean aged $53.15+11.47$ years, referred to a sleep medicine outpatient center placed in Constanta, Romania, and diagnosed with BRSD, more than a half were identified with obstructive sleep apnea ( $n=204 ; 66.66 \%)$. The distribution of 102 non OSA patients included other BRSD (10 cases of central sleep apnea, 14 with obesity hypoventilation syndrome and 78 with upper airways resistance syndrome). The majority of nonOSA patients were males $(n=222 / 306 ; 72.54 \%)$ without differences among groups (OSA versus nonOSA), although the proportion of women was larger in nonOSA group (tabel 1). There were significant differences of distribution of cases by gender $(p<0.002)$, smoking status and levels of eCO measurements (table 1).

Females were older than males $(57.55$ years +10.06 SD versus 51.76 years $+11.28 ; F=16.987, p=0.0005)$, with $78 \%$ of cases in the 6th and 7th decade of age compared to males who had a normal distribution. Anthropological measurements NC and WC measured in centimeters revealed significant differences of NC by gender $(44.15 \mathrm{~cm} \pm 3.08 \mathrm{SD}$ in men versus $40.48 \mathrm{~cm} \pm$
3.20 SD in women, $p=0.000$ ), according to the decades of age $(F=2.637 ; p=0.024)$, and significant correlations of CG values with the number of sleep apneas $(r=-0.207$; $p=0.000)$, nocturia $(r=-0.207 ; p=0.000)$ and daytime sleepiness $(r=-0.275 ; p=0.000)$. The mean value of WC was $108.56 \mathrm{~cm} \pm 10.358$, with no influence by age $(F=1.981 ; p=0.081)$ but significantly higher in males compare to females women $[109.89 \mathrm{~cm} \pm 9.80$ SD versus $105.03 \mathrm{~cm} \pm 11.01 \mathrm{SD}$. WC; $F=14.831 ; p=0.000)$. WC was corellated to apneas $(r=-0.208 ; p=0.000)$, nocturia $(r=-0.178 ; p=0.001)$ and day sleepiness $(r=-0.346$; $p=0.000$ ). BMI was slightly higher in women than men $\left(34.34 \mathrm{~kg} / \mathrm{m}^{2} \pm 7.14 \mathrm{DS}\right.$ and men $33.51 \mathrm{~kg} / \mathrm{m}^{2} \pm 6.26 \mathrm{DS}$; $F=1.060 ; p=0.304$ ), significantly correlated with nocturia $(r=-0.182 ; p=0.001)$, dyspnoea $(r=-0.168 ; p=0.002)$ and diurnal sleepiness $(r=-0.301 ; p=0,000)$. Overall, all anthropometric measures are in relatioship with OSA patients' symptoms.

Smoking status of patients was quite similar in both groups ( $p>0.05$ ) (table 1 ), with slightly more active smokers (39.7\%) in OSA group.

Average eCO was higher in OSA cases $(U=11871.5$, $p=0.044)$ (fig. 1).

A possible confounder might be considered the significant difference of $\mathrm{BMI}$ among OSA versus nonOSA patients. An increased activity of heme oxygenase, with elevated levels of eCO, has been described in obese patients as a protective mechanism against inflammation [16]. However, in our study, there was no correlation between $\mathrm{BMI}$ and eCo neither in the study group ( $F=2.103$, $p=0.141)$, nor in OSA $(F=1.629, p=0.20)$ or nonOSA $(F=2.647, p=0.106)$ subgroups; therefore, it is not likely

\begin{tabular}{|l|c|c|c|c|}
\hline Characteristics & $\begin{array}{c}\text { Total BRSD } \\
\text { (mean } \pm \text { SD) }\end{array}$ & OSA (mean + & $\begin{array}{c}\text { nonOSA (mean + } \\
\text { SD) }\end{array}$ & P \\
\hline Patients (nr; \%) & 306 & $204(66.7 \%)$ & $102(33.3 \%)$ & \\
\hline Age (years) & $53.15 \pm 11.47$ & $52.84 \pm 10.61$ & $54.36 \pm 12.41$ & 0.2657 \\
\hline Gender (M/F) & $222 / 84$ & $160 / 44$ & $62 / 40$ & 0.0011 \\
\hline NC (cm) & $43.15 \pm 3.51$ & $44 \pm 3.45$ & $41.67 \pm 3.14$ & 0.0000 \\
\hline WC (cm) & $108.56 \pm 10.36$ & $111.71 \pm 10.29$ & $103.43 \pm 8.42$ & 0.0000 \\
\hline BMI (kg/m $\left.{ }^{2}\right)$ & $33.73 \pm 6.5$ & $35.21 \pm 6.71$ & $31.62 \pm 5.5$ & 0.5525 \\
\hline Active Smokers & 115 & 81 & 34 & 0.0000 \\
\hline Never Smokers & 102 & 66 & 36 & 0.0000 \\
\hline Former Smokers & 89 & 57 & 32 & 0.0000 \\
\hline eCO (ppm) & $8.14 \pm 9.92$ & $9.10 \pm 10.64$ & $6.25 \pm 7.99$ & 0.017 \\
\hline
\end{tabular}

Legend: OSA = obstructive sleep apnea; $\mathrm{BRSD}=$ breathing related sleep disorders; $\mathrm{NC}=$ neck circumference; WC

$=$ waist circumference; $\mathrm{BMI}=$ body mass index; $\mathrm{eCO}=$ exhaled $\mathrm{CO} ; \mathrm{M}=$ male; $\mathrm{F}=$ female $; \mathrm{SD}=$ standard deviation
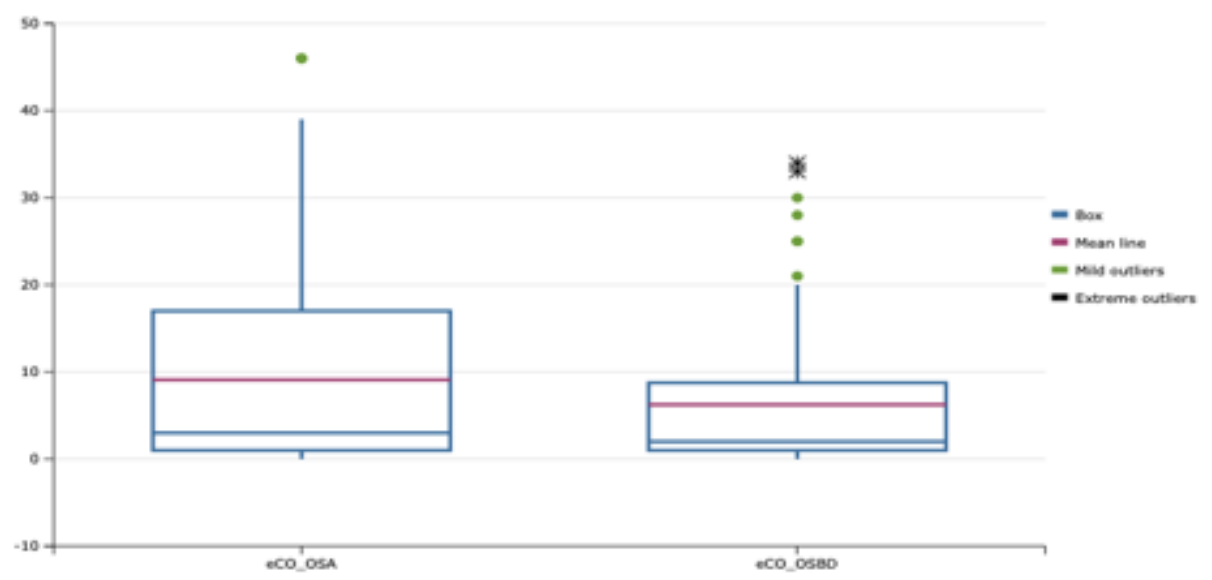

Fig. 1. The levels of exhaled CO in obstructive sleep apnea patients (OSA) compare to cases with other breathing related sleep disorders (nonOSA)

Table 1

DESCRIPTIVE STATISTICS OF STUDY GROUP 
Table 2

AVERAGE eCO LEVELS IN ACTIVE SMOKERS ACCORDING TO THE COMORBIDITIES OF THE BREATHING RELATED SLEEP DISORDERS

\begin{tabular}{|c|c|c|c|c|}
\hline \multirow[b]{2}{*}{ Comorbidities } & \multicolumn{2}{|c|}{ OSA active smokers } & \multicolumn{2}{|c|}{ nonOSA active smokers } \\
\hline & Number & $\begin{array}{l}\mathrm{eCO}(\mathrm{ppm}) \\
\text { Mean+SD }\end{array}$ & Number & $\begin{array}{l}\mathrm{eCO}(\mathrm{ppm}) \\
\text { Mean+ SD }\end{array}$ \\
\hline \multirow{2}{*}{$\begin{array}{l}\text { Obstructive lung } \\
\text { diseases }\end{array}$} & Yes $(n=34)$ & $22.88 \pm 11.01^{*}$ & Yes $(n=13)$ & $15.46 \pm 8.51$ \\
\hline & No $(n=47)$ & $17.81 \pm 7.29$ & No $(n=21)$ & $15.28 \pm 8.95$ \\
\hline \multirow{2}{*}{ COPD } & Yes $(n=31)$ & $23.61 \pm 10.84^{*}$ & Yes $(n=9)$ & $16.22 \pm 6.77$ \\
\hline & No $(n=50)$ & $17.66 \pm 7.49$ & No $(n=25)$ & $15.04 \pm 8.52$ \\
\hline \multirow{2}{*}{ Asthma } & Yes $(n=4)$ & $16.25 \pm 10.01$ & Yes $(n=5)$ & $14.2 \pm 5.81$ \\
\hline & No $(n=77)$ & $20.13 \pm 9.32$ & No $(n=29)$ & $15.55 \pm 8.39$ \\
\hline \multirow{2}{*}{ Cardiovascular diseases } & Yes $(n=45)$ & $18.82 \pm 8.74$ & Yes $(n=11)$ & $16 \pm 7.16$ \\
\hline & No $(n=36)$ & $21.33 \pm 9.95$ & No $(n=23)$ & $15.04 \pm 8.52$ \\
\hline \multirow{2}{*}{$\begin{array}{l}\text { Cerebrovascular } \\
\text { diseases }\end{array}$} & Yes $(n=1)$ & 22 & Yes $(n=2)$ & $15.5 \pm 0.71$ \\
\hline & No $(n=80)$ & $19.91 \pm 9.37$ & No $(n=32)$ & $15.34 \pm 8.26$ \\
\hline \multirow{2}{*}{ Metabolic syndrome } & Yes $(n=11)$ & $22.82 \pm 11.48$ & Yes $(n=5)$ & $17.8 \pm 8.29$ \\
\hline & No $(n=70)$ & $19.49 \pm 8.95$ & No $(n=29)$ & $14.93 \pm 8.03$ \\
\hline \multirow{2}{*}{ Type 2 diabetes } & Yes $(n=13)$ & $23.15 \pm 10.59$ & Yes $(n=7)$ & $17 \pm 6.93$ \\
\hline & No $(n=68)$ & $19.32 \pm 9.02$ & No $(n=27)$ & $14.92 \pm 8.33$ \\
\hline \multirow{2}{*}{$\begin{array}{l}\text { Other endocrinological } \\
\text { diseases }\end{array}$} & Yes $(n=2)$ & $8,00 \pm 2,82$ & Yes $(n=3)$ & $9.66 \pm 5.86$ \\
\hline & No $(n=79)$ & $20,24 \pm 9,23$ & No $(n=31)$ & $15.9 \pm 8.04$ \\
\hline \multirow{2}{*}{$\begin{array}{l}\text { Ear Nose Throat } \\
\text { diseases }\end{array}$} & Yes $(n=24)$ & $20.29 \pm 9.05$ & Yes $(n=6)$ & $13.83 \pm 7.70$ \\
\hline & No $(n=57)$ & $19.79 \pm 9.51$ & No $(n=28)$ & $15.67 \pm 8.17$ \\
\hline \multirow{2}{*}{ Psychiatric diseases } & Yes $(n=1)$ & 13 & Yes $(n=5)$ & $23.8 \pm 10.06$ \\
\hline & No $(n=80)$ & $20.03 \pm 9.34$ & No $(n=29)$ & $13.89 \pm 6.79$ \\
\hline
\end{tabular}

that $\mathrm{BMI}$ is interfering this result. Another potential factor of influence could be the gender distribution, as women has generally lower muscle mass and myoglobin to bind $\mathrm{CO}$, or the elimination rate of $\mathrm{CO}$ is lower in men [17]. On the other side, loss of muscle mass and functionality is frequent in OSA [18] and might counterbalance this effect. Men were, proportionally, more in the OSA group and significant difference was found between eCO increased levels in men with BRSD versus women (9.32 mean, 4 median value in men versus 5.06 mean, 2 median in women; $U=11113.5 ; p=0.0096)$, but these differences were not reproduced within subgroups $(U=4140, p=0.074$ in OSA and $U=1447.5, p=0.155$ in nonOSA).

Active smokers represented $37.58 \%$ of BRSD patients $(n=115 / 306)$, and the majority of them were diagnosed with OSA ( $n=81 / 115 ; 70.43 \%)$. The average of eCO levels was higher in OSA (19.94 ppm $\pm 9.32 \mathrm{SD})$ versus nonOSA patients ( $15.35 \mathrm{ppm} \pm 8.01 \mathrm{SD} ; \mathrm{F}=6.274 ; p=0.014$ ), with significant increased levels in OSA active smokers, by gender (men had higher eC0: $21.09 \mathrm{ppm} \pm 9.26 \mathrm{SD}$ versus women: $13.92 \mathrm{ppm} \pm 7.35 \mathrm{SD} ; \mathrm{F}=6.924 ; p=0.010$ ). In OSA patients, active smoking had a $100 \%$ specificity $(n=66 /$ $66)$ and the highest sensitivity $(96.3 \%, n=78 / 81)$ at a threshold value of the eCO $\geq 6 \mathrm{ppm}$. Up to date, there was no specific threshold described for the defining active smokers in OSA. It is estimated that a normal level of eCO for a non smoker is $4 \mathrm{ppm}$ and a value of $7 \mathrm{ppm}$ would mark the line between the smokers and the non-smokers [20], although other researchers have found a wider range, from 6 [18] to $10 \mathrm{ppm}$ [21]. The threshold level for eCO found in this study is very important for two reasons: firstly, because it is not a general threshold, but a specific one for OSA patients and, secondly, because all OSA patients should be included in smoking cessation programs, particularly if they might be at risk during their current occupation [22]. Finnally, the levels of eCO were evaluated in relation with the main comorbidities of OSA (table 2), which might have an influence on the symtoms and the overall quality of life in lung patients [23]. The mean value of eCO was significantly increased in OSA patients, active smokers, with associated COPD [24]. All other comorbidities added no supllementary differentiation among the patients' groups.

\section{Conclusions}

In this research, eCO distinguishes patients with OSA from other breathing related sleep disorders nonOSA. Male gender and COPD overlapping OSA are the risk factors of increased eCO levels in smokers. A threshold of eCO $\geq 6$ ppm could be asigned for the identification of the active smokers among OSA patients.

\section{References}

1.VERHOEFF, A.P., VAN DER VELDE, H.C.M., BOLEIJ , J.S.M., LEBRET E, BRUNEKREEF B. Int. Arch Occup Environ Heath. 53, nr 2, 1983, p.167.

2.BATHOORN, E., SLEBOS, D.J., POSTMA, D.S., KOETER, G.H., VAN OOSTERHOUT, A.J.M., VAN DER TOORN, M., BOEZEN, H.M., KERSTJENS, H.A.M. Eur Respir J. 30, nr 6, 2007, p. 1131.

3.DEVECI, S.E, DEVECI, F., AÇIK, Y., OZAN, A.T. Respir Med. 98, nr 6, 2004, p. 551.

4.AZUMA, M., MURASE, K., TACHIKAWA, R., HAMADA, S., MATSUMOTO, T., MINAMI, T., INOUCHI, M., TANIZAWA, K., HANDA, T., OGA, T, et al. J Appl Physiol. 122, 2017, p. 104.

5. OTELEA, M.R., TRENCHEA, M.,ARGHIR, O.C., VELESCU, L., DANTES, E., BECHIR, E.S., ELSAAFIN, M., RASCU, A., Rev. Chim. (Bucharest), 69, no. 1, 2018, p. 282-285

6. BECHIR, E.S., BECHIR, A., ARGHIR, A.C., CIAVOI, G., GIOGA, C., CURTMOLA, F., DASCALU, I.T., Mat. Plast., 54, no. 2, 2017, p. 304-307 7.OTTERBEIN, L.E., BACH, F.H., ALAM, J., SOARES, M., et al. Nature Medicine 6, 2000, p. 422.

8.ZAYASU, K., SEKIZAWA, K., OKINAGA, S., YAMAYA, M., OHRUI, T., SASAKI, H. Am J Respir Crit Care Med, 156. nr 4Pt1, 1997, p. 1140. 
9.ZHANG, J., YAO, X., YU, R., BAI, J., SUN, Y., HUANG, M., ADCOCK, I.M., BARNES, P.J. Respir Res. 11, 2010, p. 50.

10.ZETTERQUIST, W., MARTEUS, H., JOHANNESSON, M., NORDVAL, S.L., IHRE, E., LUNDBERG, J.O., ALVING, K. Eur Respir J. 20, nr 1, 2002, p. 92.

11.RAIFF, B.R., FAIX, C., TURTURICI, M., DALLERY, J. Nicotine Tob Res. $12 \mathrm{nr}$ 8, 2010, p. 834.

12.MOSCATO POSCIA, A., GARGARUTI, R., CAPELLI, G., CAVALIERE, F. BMC Pulm Med. 14, 2014, p. 204.

13.*** SRNT SUBCOMMITTEE ON BIOCHEMICAL VERIFICATION. Nicotine Tob Res, 4, nr 2, 2002, p.149.

14.IBER, C., ANCOLI-ISRAEL, S., CHESSON, A.L JR. QS for the AA of SM. The AASM manual for the scoring of sleep and associated events: rules, terminology and technical specifications. 1st ed. Westchester, IL: American Academy of Sleep Medicine. 2007.

15.BERRY RB, GAMALDO CE, HARDING SM, LLOYD RM, MARCUS CL, VAUGHN BV. The AASM Manual for the Scoring of Sleep and Associated Events: Rules, Terminology and Technical Specifications, Version 2.0.3. Darien, IL:American Academy of Sleep Medicine 2014
16.ABRAHAM, N.G., JUNGE, J.M., DRUMMOND, G.S. Trends Pharmacol Sci. 2015, 37, nr 1, 2015, p. 17.

17.SANDBERG, A., SKOLD, C.M., GRUNEWALD, J., EKLUND, A., WHEELOCK, A.M. PLOS ONE, 6, nr 12, 2011, p. e28864.

18. RASCU, A., POPA, D.E., ARGHIR, O.C., OTELEA, M.R., Farmacia, 64, no. 6,2016, p. 819

19.*** EUROPEAN NETWORK FOR SMOKING AND TOBACCO PREVENTION (ENSP) GUIDELINES FOR TREATING TOBACCO DEPENDENCE, 2016; http://elearning-ensp.eu/assets/English\%20 version.pdf

20.MIDDLETON, E.T., MORICE, A.H. Chest, 117, nr 3, 2000, p.758

21.WALD, N.J., IDLE, M., BOREHAM, J., BAILEY, A. Thorax, 36, nr 5, 1981, p. 366

22. RASCU, A., ARGHIR, O.C., OTELEA, M., Rom J . Leg Med, 24, no. 2, 2016, p. 118

23.MACNEE W. Proc Am Thorac Soc, Vol 2. pp 50-60, 2005. 24. OTELEA, M.R., ARGHIR, O.C., ZUGRAVU, C., NAGHI, E., ANTONIU, S., RASCU, A., Rev. Chim. (Bucharest), 69, no. 2, 2108, p. 346

Manuscript received: 21.02 .2019 